\title{
'AIMATA, QUEEN POMARE IV: THWARTING ADVERSITY IN EARLY 19TH CENTURY TAHITI
}

KAREN STEVENSON

University of Canterbury, Christchurch

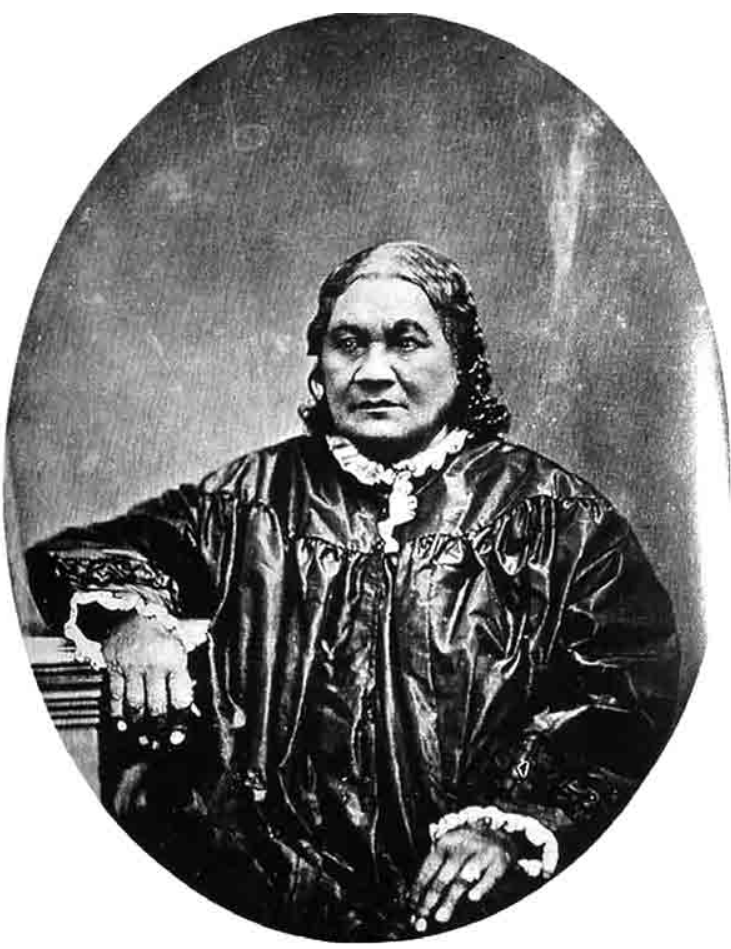

To tell the story of "Aimata, Pomare IV is to tell a story of change. Queen Pomare IV reigned as monarch of Tahiti for 50 years (1827-77). During this time Christianity became commonplace, ari ' $i$ (chiefs in the traditional political system) became legislators (in a European political system) and Tahiti became French. Pomare IV has been frequently depicted as an inept ruler, at best a figurehead. It was her "fault" that the French took "possession" of Tahiti, and perhaps her "fault" that the traditional system of leadership seemed to fade away. These 19th-century assessments of both the British and French have created a distorted image of the woman and her reign as politically 
incompetent, when they might be seen otherwise as politically astute, rife with intrigue and manipulation. Instead of viewing Pomare as the pawn of missionaries and consulates, this essay will demonstrate the unprecedented position she created as Queen Pomare IV.

'Aimata, first-born of Pomare II, was destined to be a woman of stature within the traditional social system of Tahiti. She was born sometime between 1810-1813, ${ }^{1}$ before the adoption of Christianity in Tahiti. She inherited mana and a presence associated with her rank. From her father, who had consolidated the titles of Tahiti after a victory at Fei Pi (1815), ${ }^{2}$ she held title to Tahiti. Her mother, Teremoemoe, from the Tamatoa line linked her to Ra'iātea and Huahine; with her marriage to Tapoa she was tied to Bora Bora. She could easily assert her position as a powerful or "great woman" (Gunson 1964) of Tahiti. However, this interpretation is quite different from that of Pere O'Reilly (1972: 2): “Elle est fille adulterine de Pomare II, la fille d'une femme que les missionaries designent pudiquement comme une 'epouse surnumeraire' du roi." 3

It is clear that the missionaries, in their role as chiefly advisors, misunderstood the position of "Aimata and consequently ignored her. The foundation of a patrilineal monarchy was established by Pomare II, ${ }^{4}$ which allowed the missionaries to sidestep the traditional status system. Teinaiti, a younger brother born in 1817 became the heir. The missionaries ${ }^{5}$ of the London Missionary Society (LMS) were pleased that the Pomare line would continue. Unfortunately this infant heir died within the year and British concern about the viability of the Pomare dynasty heightened. Pomare II followed established custom by adopting Tapoa II of Bora Bora in 1820, the adoption conferring all the rights of a son. An heir was now in position within both the traditional framework as well as acceptable Christian patrilineal succession. Tapoa's claim was reinforced when he married 'Aimata in the same year. ${ }^{6}$ All of this political manoeuvering, however, was put to the side with the birth of another son, Teri'itaria (also in 1820), to Pomare II.

At the death of Pomare II in 1821 the missionaries and other European advisers to the "crown" were in a quandary. Should they observe Tahitian social structure and consent to support the succession of an adopted son, or follow their own tradition and support an infant King? The choice was an easy one. In 1824 the LMS missionary Henry Nott crowned Teri'itaria as Pomare III with a great deal of pomp and ceremony. He also took advantage of the Regency so established to request of George IV, in the name of Pomare III, an English flag and British protection over Tahiti (Newbury 1961: 234). The missionaries also undertook the training of this youth.

April 21, 1824, he was taken into the institution at Afareaitu with the miss. children, and was making a very pleasing progress in the English language, 
and in reading and writing when death put a period to his life and to the fond expectations of all parties Jan 11th 1827. (Newbury 1961: 234)

The death of Pomare III in 1827 at the age of six-and-a-half years was a blow to Nott and his colleague George Pritchard. They had hoped to create both the ideal king as well as ensure for themselves a position of privilege. Reluctantly, as their aspirations for a monarchy were in jeopardy, they turned to 'Aimata.

At a meeting of chiefs, 'Aimata was invested as Pomare Vahine. This delegation of authority was done with little official pomp; all involved were uncertain of the outcome. The missionaries had previously ignored 'Aimata. She was a young girl of strong character not easily influenced by missionary doctrine; she would not be easily manipulated. She had not accepted Christianity and was, therefore, seen as a problem both to the mission and the creation of an ideal monarchy. The missionaries questioned whether the chiefs would pay her deference; the chiefs, in turn, were uncertain about what the elevation of Pomare IV would mean to them. Wanting to consolidate their own position vis-á-vis the Pomare women ("Aimata, Teremoemoe, Teri' itaria ${ }^{7}$ ), and perhaps regain the position they held prior to the battle of Fei Pi, the chiefs formed an uneasy alliance with the missionaries. The result was a decade of political manoeuvring as all the players sought positions within the monarchy of Pomare IV.

\section{THE EARLY YEARS 1827-38}

The missionaries' apprehensions about Pomare IV were well founded. During what has been termed the Regency period (1821-27) "the journals of the Tahitian missionaries are filled with reports of lawbreaking and the scheming of the chiefs" (Gunson 1962: 213). There were many reversions to "heathenism", ${ }^{8}$ as the chiefs jockeyed for position and power. Within the traditional structure, chiefs were privileged, although many of their rights had been revoked by the Pomare Code of $1819,{ }^{9}$ which established rules of conduct in a Christian era. But without Pomare II to enforce the Code, a return to the old rules of behaviour appeared especially likely where they reinforced rank and status.

In contrast, the strategy of Tati and Utami, chiefs of Papara and Puna'auia respectively, was to align themselves with the missionaries and the Pomare Code.

As governors and judges under the law, they retained much of the power, which they had been in danger of losing under Pomare II. Under the Regency, they attempted to consolidate power and build up their prestige. As Supreme Judges of Tahiti, they gathered around themselves much of the old pomp of their former high chiefly status. (Gunson 1962: 222) 
In so doing they also set themselves in opposition to Pomare IV.

Pomare IV was seen to be a key player in the reversion to "heathenism". Her court was "a virtual centre of 'heathen' resistance to missionary teaching" (Gunson 1962: 228) as well as to the laws of her father. She delighted in watching dance performances and was apt to demand tribute-practices prohibited by the Pomare Code. "Her companions were reminiscent of 18th century arioi - mostly 'wild young men' who practiced tattooing, made cider from fermented mangoes, and slept and ate with the royal couple" (Newbury 1980: 60). She also appeared to be sympathetic to the mamaia movement, which was not only anti-missionary but made a mockery of Christianity (Gunson 1962: 212).

This movement was met with hostility by the chiefs who were using their association with the missionary as a means to power. Tati and Utami expelled from their districts any person that displayed an interest in the mamaia. This allowed for the consolidation of the movement in Pape'ete (where Pomare was located), which in turn fuelled the political tensions between her and the chiefs. Chiefs of lesser status who had not acquired the position of legislator were more willing to support Pomare, almost certainly hoping to be offered lands or titles as reward. The missionaries viewed Pomare's activities as "youthful lapses of character" (Newbury 1961: 327). However, this realignment of chiefs demonstrated an acute ability on the part of Pomare to manipulate the traditional political system.

In 1827 Vaira'atoa, a well-respected and very powerful chief, suggested that certain laws in the Pomare Code be revoked, particularly ones dealing with tribute and the presentation of cloth. His alignment with Pomare IV is thus clear, as restoration of these practices would help consolidate her position. It is also clear that the mission regarded this suggestion as anti-church and anti-law. Matthew Crook (a missionary from Vaira'atoa's district) wrote: "... the old chiefs make very much of them [Pomare and her husband], present them with large heaps of cloth and seem inclined to do away with the laws and set up many of the old customs again" (in Newbury 1980: 60). The inability or unwillingness of the missionaries to understand the politics of the situation positioned them as onlookers. Tati and Utami stood firm on their position as legislators. By December 1828 they threatened 'Aimata with court proceedings and told her that she was not above the law. She backed down, but only for the time being.

As Pomare and Vaira'atoa jockeyed against Tati and Utami tensions mounted. In 1829-30 Pomare countered with the "cloth incident". According to the Pomare Code, as Pomare IV she was paid an annual stipend in lieu of tribute. She asked the people of Mo'orea and Tahiti to provide her with cloth to offer to Leeward chiefs when they came to visit her in these places. 
Such requests had been customary ten years earlier, but her enemies saw the requests as an attempt to prove titular superiority (which she had) and threatened her with jail for breaking the law. Political intrigue always seems petty in hindsight, yet missionary John Orsmond noted at the time "that the charge that Pomare wished to do away with all law was a mere made up tale... trumped up by the chiefs to give colouring to their ill found opposition" (Gunson 1962: 230-31).

In 1830-31 Tapoa, 'Aimata's husband, found himself embroiled in a power struggle with the chiefs of Huahine (the family of his wife's mother). This allowed for another opportunity for alliances to shift and a readjustment of the power structure. When Tapoa led warriors against Huahine, he was imprisoned. Pomare IV took advantage of his imprisonment to rid herself of Tapoa. She then took as a second husband, Ari' ifa' aite of Huahine. Missionary Nott condoned this action by marrying them. His participation signalled a new alliance between Pomare IV and the missionaries. Thus, her old foes Tati and Utami also found themselves "aligned" with her. She was already aligned with the Leeward group through blood and marriage.

Pomare IV's allies in the "cloth incident" opposed this new alliance of Pomare, Nott and the Tahitian judges. Mo'orea and Taira'apu (eastern Tahiti) took the Queen to court, asserting that it was against the law to divorce, and lost. The Queen was above the law. An armed revolt ensued in which Pomare and her new allies quite effectively squashed the rebellion. This "put an end to attempts to restore the former customs of Tahiti, and to organised political agitation" (Gunson 1962: 236). The Queen confirmed her alliance with the missionaries by being baptised in 1836 . For the time being, the judicial system of the islands was on her side.

Ian Campbell (1992: 79) has noted that "Polynesian history shows unremitting calculation and determination to seize whatever advantages circumstances offered". Pomare's shift of allegiance is a clear example of this opportunism. Pomare rightly understood the power that the legislators (Tati, Utami, Hitoti, Pa'ofai) wielded within the structure of the To'ohitu (judicial body set up under the Pomare Code). ${ }^{10}$ She also understood how to optimise her own position in relation to these legislators. At the same time, manipulating the traditional political system with all its intricacies was a game deftly played by Pomare and her adversaries, and both sides quickly learned how to hold the missionaries at bay.

Another factor in this strategy was the necessity for control of a burgeoning trade and an increase in the number of foreigners living in Tahiti. Traders, whalers and sailors were more problematic than internal tensions, and "equally undesirable from the missionary point of view" (Orsmond in Newbury 1961: 352). The influx of foreign goods and the markets they 
established did not balance the disease, drunkenness and disorder that came with them. Pomare realised that she needed the law and the missionaries to control other Europeans and their interests. It was not uncommon to see up to ten ships in port at any time. With this influx came the creation of visitor entertainments in the form of grog-shops, billiard rooms and prostitution (Newbury 1961, 1980). Drunken and disorderly behaviour was common, as were altercations between and within ships' companies, and attempts to control foreign behaviour were not readily accepted. The Pomare Code, once the foe of Pomare IV, became her prime weapon.

The Code was enforced by mutoi 'police', who were often lesser chiefs within the traditional system, and as protectors of the peace they had to answer only to the court. Most offences were punishable by fines and their salaries were paid from these fines. Thus "Queen Pomare's constables, enforced these laws in an undiscriminating fashion by placing both the guilty and the suspect in the stocks" (Newbury 1961: 333). Visitors (whalers and traders) were not at all happy with this new morality.

The Code of Laws was revised and extended to Europeans. Now included was a section prohibiting unauthorised immigration, traffic in spirits and women, and the sale of land. These prohibitions gave the Tahitians stronger ground from which to legislate the movements of the foreigner. The To'ohitu court had the sole responsibility of administering the law, yet where Europeans were involved, their decisions were more difficult to enforce (Newbury 1961: 333). Missionaries often interfered with this legislative process as they believed the "judges and chiefs were so merciless and inflexible in their interpretation and enforcement of the law" (Campbell 1992: 77). At the same time, missionaries and businessmen of Papeete

... busied themselves collecting evidence for the courts, or giving advice to the Queen and the chiefs on how to modify the law.... Civil and religious affairs were not inseparable in the eyes of traders in the stocks, spirit vendors whose stores were confiscated, or Catholic missionaries who were deported or forbidden by law to preach. (Newbury 1961: 334)

Ships' captains often complained of mistreatment and misdealing, which fuelled a debate as to the powers of the throne. Did the monarchy have jurisdiction over foreigners - especially since it appeared that foreigners managed the monarchy?

Politics had changed. Pomare and the To'ohitu had realigned themselves to consolidate their power and now they saw that authority diminishing. Foreigners would sooner be "policed" by Tahitians, but resented all actions taken against them. The To 'ohitu were unable to control the flagrant breeches of the law that ensued. The monarchy found itself "a subject for debate between 
rival consuls and naval officers, and finally between rival European powers" (Newbury 1961: 334). It was during this period that George Pritchard became the adviser to the Queen. ${ }^{11}$ This alliance was created by the necessity to work with foreign markets and representatives. She needed someone she could trust to interpret not only the language but also the movements of the foreigners. Pritchard spoke impeccable Tahitian; Pomare refused to speak English.

The alliance with Pritchard could be seen as an astute move on the part of Pomare. Linking herself with a man whom she considered to be the most powerful of the missionaries, she was able to more easily delegate authority over the foreign element. Yet this was a new "game", one about which she was uncertain. The authority and alacrity with which she manipulated the traditional system attests to her abilities, but this new game was different. Under the guise of "authority", issues of gender can easily be detected. Ralston (1992: 174-75) commented that:

... for chiefly women who had exercised authority over certain resources and labour in precontact times, and who had figured prominently in societies where descent and inheritance were reckoned ambilineally, the changes must have been acute and rapid. For many they would have occurred in the early contact period before formal colonial rule was imposed. Foreign naval captains, explorers, traders and later colonial officials expected to deal with male rulers and traders, and when faced with questions of inheritance to power or property they placed greatest weight on male primogeniture.

Ships' captains did not want to interact with Pomare; they found her evasive, noncommittal, yet demanding. They also found her confidant, George Pritchard, unbearable because of his Christian ethics - ethics which Pomare appeared to uphold. Nevertheless homage was paid. This indignity was further acerbated when these men found that they shared their audience with the Queen and her child. This reinforced the bitter taste of showing obeisance to a woman and was reflected in the contempt many felt towards her. It was at this time that her reputation as a pawn or a woman of little brain came into being. Journal entries read as a caricature. On the one hand, Martin (1981: 59) wrote: "She looked every bit the Queen..., Poor woman! She seemed conscious that all this finery was out of character for she had not been five minutes in the cabin before she pitched her bonnet on the sofa and kicked off her shoes." Wilkes, on the other hand, alludes to her position (1852: 140): "The queen, however, contrives to rule in all matters that rightfully belong to her...", and Dumont D'Urville (Rosenman 1992: 147) described "an audience with Queen Pomare who did whatever Pritchard told her and, caught between the missionaries and the French warships, the poor little woman was out of her depth. She nursed her young baby throughout the interview". 
Foreign officials were obliged to pay her homage even though they did not want to recognise her authority. The animosities that gender created were coupled with a very patronising attitude and created a difficult political situation for Pomare. To these officials she was a young girl, not a figure of authority. We have, therefore, a politically astute and powerful woman who was surrounded by and entrusted herself to men (Pritchard and her Tahitian advisors) in order to successfully regulate foreign intervention. Uncomfortable in this position, she attempted to reassert her dominion via the traditional status system - with titles linked to land. This fuelled the rivalry between herself and the To 'ohitu chiefs, who dealt with issues of land tenure as well as the creation and implementation of Tahitian law. Pomare was involved in land disputes and "had made several attempts to assume the land titles of families that had died out, but she had been opposed by the To 'ohitu" (Newbury 1980: 101).

It was at this time that she began to establish her own dynasty. Between 1835 and 1847 she gave birth to nine children: three died in infancy, another died at 17. Engrossed in producing potential heirs and with the settlement of land disputes, Pomare spent most of her time in Mo'orea, away from Tahiti. In her absence she placed her faith and trust in Pritchard and her Tahitian advisers. However, these absences allowed her adversaries an opportunity and they quickly took advantage of it. Status rivalry resulted in "difficulties posed by chiefs who resented her authority, and by traders and a consul who sought to embarrass her for their own political or commercial gain" (Campbell 1992: 77). The To "ohitu remained an irritation for Pomare as they continued to assert their ever-changing political positions.

\section{THE FRENCH}

Louis Antoine de Bougainville, captaining L'Etoile and La Boudeuse, dropped anchor off Tahiti on 6 April 1768. He proceeded to annex Tahiti for the French, but was made aware upon his return to France, that Wallis had already annexed it, in the name of King George IV, seven months before. ${ }^{12}$ Tahiti enchanted Bougainville and his glowing and romantic descriptions were soon firmly lodged in the minds of the French. These descriptions, however, made it ever more difficult to accept the British as "owners" of the island. The Spanish, too, tried to lay claim to Tahiti on visits in 1772 and 1774. In 1774 two Catholic missionaries were left in the district of Tautira. It was most likely the problems they created for the Pomares that led to Pomare IV's decision to expel French Catholic missionaries 60 years later.

The politics of power and status remained crucial to Pomare's government. Her relationship with Pritchard continued to provoke a growing antagonism between herself and the To'ohitu on the one hand and foreign immigrants, especially French immigrants, on the other. In 1836 a crisis began with the 
expulsion of three French nationals, two of them Catholic priests. They had entered Tahiti illegally and the To'ohitu decided that they should be deported. Jacques Antoine Moerenhout, the French consul, a practising Catholic and adversary of Pritchard, played this event as both a national and religious issue. The chiefs had passed new port regulations in 1836 making all landings subject to the discretion of the Tahitian government (Newbury 1980: 93). However, when Admiral Dupetit-Thouars arrived in 1838 he demanded reparations for the expulsion of the Frenchmen. The following month Admiral Durmont D'Urville reprimanded Pomare for the actions of her government. She suggested that the priests would be welcomed, yet two months later Pomare and the To 'ohitu reinforced their position with a new law disallowing the teaching of Catholicism. Not knowing when a French mano'-war might appear in her waters leaving Tahiti exposed to French intrigue and oppression, Pomare and her chiefs wrote to Queen Victoria asking for Her Majesty's protection (Pritchard 1983: 58). Pritchard was the conveyor of this letter, and the hope was that he would return with the promise of protection.

Even though Pomare and the chiefs seemed firmly aligned, the chiefs still resented Pritchard's influence. As such, Moerenhout took advantage of Pritchard's absence to lure the To'ohitu to his side. It was in this atmosphere of uncertainty and mistrust that Moerenhout was able to work for the downfall of Pomare's government. He continued to gather evidence of mistreatment of French nationals. These involved a series of complaints by the French settlers about seizure of contraband spirits, prohibition of land sales and conduct of the mutoi; all were in essence complaints about the jurisdiction of the To 'ohitu, whose inability to control the police as well as secure a safe environment gave Moerenhout the upper-hand in his dealings with them. This led some of the senior chiefs to request assistance. Moerenhout drafted a letter to himself and coerced Tati, Utami, Hitoti and Paraita to sign it. It read:

On account of the growth of evil in this land, among certain foreigners residing here, who are breaking our laws and Regulations of the land, who kill people and commit all manner of crimes, being protected by influential persons residing here as the Representatives of Countries where those crimes are punished [with] greater rigour than in ours - please send a war ship. (Pritchard 1983: 78)

With this in hand, as well as various French complaints, Moerenhout was in a strong position in 1842 when Dupetit-Thouars arrived.

In August 1842 Pomare was absent at Mo'orea awaiting the birth of a child and Pritchard was in England. Moerenhout and the chiefs now had the opportunity to undermine Pomare's government. Dupetit-Thouars had orders to create a "port of protection" for French commercial activities in the Pacific. He had tried to establish one in the Marquesas, but internal difficulties led 
him to abandon that idea (Newbury 1980: 105-6). Tahiti, the opportunity at hand, was far too good to turn down. After meetings with Moerenhout and the chiefs, Dupetit-Thouars demanded compensation in the form of a bond of $\$ 10,000$ within 48 hours. If this was not forthcoming then provisional occupation of the island would ensue; and if met with opposition hostilities would commence (Newbury 1980: 107).

Pomare was informed of the French demands, but never saw the complaint that substantiated it. In lieu of the money a "treaty" was signed asking for French "protection". ${ }^{13}$ Pomare was coerced into signing. This unconscionable diplomatic coup has often been interpreted as a failure on the part of Pomare. In truth she was not able to counter French warships threatening hostilities, nor was she able to control (at this time) the chiefs, who had so often aligned themselves against her. She also did not understand Britain's reluctance to protect Tahiti. Nevertheless, she was not willing to give up. Dupetit-Thouars had left an acting commissioner and six marines to maintain France's position. Neither these men, nor Moerenhout, nor the chiefs were able to control Pomare; nor could they prevent her from flying a personal house flag quartered with a crown. Pomare became the ultimate frustration of the provisional government (Newbury 1980: 110).

\section{ANNEXATION, WAR AND THE MONARCHY}

Much of Tahitian history during the reign of Pomare IV can be seen as political gamesmanship. The same is true of the annexation of Tahiti. Campbell (1992: 72) noted that:

A succession of crises in the late 'thirties over law enforcement, land ownership, trade regulations, and the residence of Catholic priests, finally brought a confrontation with the government of France in which neither the advice of missionaries, nor the structure of government inherited from Pomare II were of any use.

Pomare's ability to manipulate the traditional political system became increasingly ineffectual as Tahiti became a field of play in Anglo-French relations. Yet Pomare remained steadfast. She organised an assembly that in effect invalidated France's actions and secured "disavowals of their part of the affair [from Tati and Utami], blaming Moerenhout for the conspiracy" (Pritchard 1983). On his part, Moerenhout believed that he could intimidate Pomare with threats. On 18 January 1843 he wrote:

Be it known to Your Majesty that your land is now in the enjoyment of peace, and you, as Queen of the land. I must inform you, that should the treaty, contracted between Your Majesty and the King of the French, be violated, 
great evil will ensue. Think not that Great Britain and all the Nations can protect you from the anger of France. I say not this to frighten you, but as a friend I warn you... J.A. Moerenhout. (Pritchard 1983: 125-26)

These threats became fuel for Pomare, who truly believed that Victoria would come to her aid. Even though Pritchard returned with only empty prose, his indignation over what had transpired instilled a new vitality in Pomare. Pritchard wrote again to Queen Victoria stating that:

It is evident, beyond all doubt, that the Document, now called the "Treaty" and which four Chiefs and the Queen were obliged to sign, or lose their island, was not written by the Tahitians and presented to the French, soliciting their protection, but was written by the French and presented to the Tahitians simply for their signatures. Thus we see that the whole is a compound of falsehood and intrigue, intended to deceive the Nations of Europe, and to serve as a pretext for robbing a helpless Queen of her Sovereign rights, and enslaving Tahiti, under the name of a Naval Station, or a French Colony. (Pritchard 1983: 112)

This new flurry of correspondence created a renewed sense that Britain would insure the sovereignty of Tahiti. ${ }^{14}$ Pritchard had correctly interpreted the actions of the French as "illegal", however this did not inspire the British to act on behalf of Tahiti. This constant stirring of emotions led to the expulsion of Pritchard from the islands and became the pretext for outright annexation when Dupetit-Thouars returned in November 1843 (Newbury 1980: 110).

Again Pomare held her ground. She refused to abandon her flag, which meant she refused to accept French sovereignty. Still, the tricolor was hoisted with fanfare; fanfare that muffled the verbal protest of Mare, Pomare's orator. In turn,

Pritchard struck his consular flag and took the queen into the consulate at news of annexation. On 8 November Bruat began his governorship installed in her house with full, if unratified, powers over both groups of islands, four ships of the line, and over a thousand men. (Newbury 1980: 114)

Bruat had seized Pomare's home and some of her lands and began to set up defensive positions. This seizure of Pomare's land and threats for more "was a most unpolitic measure at this time on Tahiti... it raised frightful apprehensions - created insurmountable aversions to the French, and induced all to assemble in arms against them" (Orsmond in Newbury 1980: 114). The expropriation of ari 'i lands strengthened Tahiti's reserve and on 13 March 1844 armed opposition began.

The reshuffling of chiefly allegiance was not a political ploy. The issue had always been land, but now Tahitian sovereignty over their land was being 
threatened. The political manoeuvres of the previous decade were about power and titles associated with land and the jurisdiction those titles allowed. The French were infringing upon Tahitian land tenure. It was the chiefs who provided the leadership and organisation of the fighting contingents. The abhorrence towards the French regarding the issue of land sequestration and the arbitrary imprisonment of Tahitians should not be viewed as support for Pomare. During the Tahitian-French War the assertion of political status, the shifting of allegiances, the playing of traditional politics continued. Pomare continued to position herself as a force, sometimes opposed to and sometimes supporting the other chiefs as legislators and leaders within a new political system.

With the establishment of a French Protectorate in 1847 came the reorganisation of Tahitian district and island administration. The running of the government was placed in the hands of Pomare and the To 'ohitu and paid for by the French. Taxes and fines were no longer key to the running of the government. The administration, enriched by French funds, spent generously for services to the point where both high and low in Tahitian society had soon abandoned "all their pretended hatred of the French" (Newbury 1980: 124). This realignment with the French signalled the end of the historic political structure. Districts became divisions of the Tahitian polity, and their leaders were no longer seen as subordinate chiefs to the Pomare claim. However, status in relation to power did not die out so easily- the Queen and her family being afforded the paramount position within the institution of the monarchy. ${ }^{15}$

For Newbury, it is at this time that Pomare began her tenure as figurehead. However, she continued to maintain her interests and enhance her political position. Pomare supervised both the French administration and the To 'ohitu, and she appealed to higher sources if she felt her position threatened. The politics of intrigue that she knew so well now surrounded appointments to the To'ohitu, church offices and the French administration. The To'ohitu remained firmly in Tahitian hands and Tahitian participation in church leadership became stronger. The new entity was French administration, an administration reliant upon foreign businessmen. As such, Pomare was able to secure her influence in a traditional manner through a network of relatives within the Salmon-Brander families (see Gossler 2005).

The paramountcy so established was financed by the French. In 1847 Pomare was given a stipend of 25,000 francs (while the Governor received 60,000 and the chiefs' 600). By the end of her reign this had increased to 37,000 francs. She also had income from leased lands that amounted to 50,000 francs. Working diligently through the system of land tenure, overseeing district land courts and the Tahitian Appeal Court, she expanded her title over 
lands. She held title in 13 of Tahiti's districts and with these titles came the rights to land. In the early $1850 \mathrm{~s}$, the To'ohitu formally recognised Pomare's claims to other estates once held by Vaira'atoa, Ari'ipaea, and Teremoemoe.

In creating a dynasty Pomare did not allow the French administration to ignore or sidestep her position. She was more than a stipend and a palace; she was a factor to be reckoned with in local politics. Her tenacity included attempts at establishing a Pomare dynasty for both Tahiti and the Leeward group. Again she worked in a traditional manner, consolidating titles through marriage alliances and adoption. Her eldest daughter, Teri'imaevarua was adopted by her ex-husband Tapoa II of Bora Bora, where she became Queen in 1860. Her sons, Tamatoa, Teri'itapunui and Ari'iaue, were also placed in positions of power: Tamatoa was crowned King of Raiatea in 1857, Teri'itapunui was allocated the chiefly titles of Mahina and Ari'iaue took the title of Pomare V in $1877 .{ }^{16}$ Both Pomare V and Tamatoa V lacked the political acumen of their mother, and unfortunately were addicted to alcohol. Tamatoa was deposed in 1871, and Pomare V became a political pawn offering Tahiti to the French in 1881. Pomare IV's dynastic ambitions crumbled, and at the end of her life she witnessed the dissolution of the chiefly power she had fought for her entire life.

"Queen Pomare was a tall, dignified-looking woman, without being handsome" (Hort 1891: 30). Two Mormon missionaries in 1874 found her careworn "but still straight as an arrow, and retaining all her faculties in perfection. She attended the fashionable round of balls and enjoyed cheating Admirals and ensigns at cards" (Newbury 1980: 195).

The 19th century was a time of monumental change. Pomare worked through these changes, evolving from a non-Christian youth to a very politically shrewd stateswoman. Her reign was mired in political conflict, opposition, intrigue and foreign intervention. She, however, maintained her position and "in a sense, personified her territory (in much the same way as the British monarch she admired personified her times)" (Newbury 1980: 195). Her death in 1877 left an air of uncertainty, and as Alexander Salmon noted:

Sous les fleurs de rhétorique de certaines des allocations prononcées, se décelait en réalitél'indice d'une sorte d'inquiétude parmi les chefs et jusque dans le peuple au sujet de l'avenir du pays après la disparition de la Reine. ${ }^{17}$ (E. Salmon 1964: 173)

Pomare IV was a figurehead, perhaps - the personification of her times, indeed. With her died a Tahitian monarchy, Tahitian jurisdiction over land, and the stature of the traditional system of leadership as manifest in the ari $i$. 


\section{NOTES}

1. There is no record of the birth of "Aimata. Most sources suggest 1813 probably based on a missionary belief that she was approximately seven to ten years old in 1820 .

2. See Gunson (1964), Newbury (1961, 1980), Oliver (1974), Stevenson (1981, 1988).

3. "She is the illegitimate daughter of Pomare II by a woman the missionaries modestly designated the extra wife of the king" (my translation).

4. With the battle of Fei Pi in 1815, Pomare II consolidated his position and claimed the title of "King". Even though a "monarchy" had been established, "the outward appearance of a Polynesian Christian 'kingdom' bore little resemblance to the realities..." (Newbury 1980: 59).

5. Pomare II had aligned himself with the missionaries as a means of consolidating his position and power. His detractors commented "he never attended but one service a day, and to that he came at a late time" (Orsmond in Newbury 1961:349).

6. Even though "Aimata was clearly of high status and rank, her titles did not give her access to the marae and the ability to wear the maro 'ura (Gunson 1964, Langevin-Duval 1979). Her marriage to Tapoa gave her access through him to the marae, thereby strengthening the Pomare ascendancy and ideally giving their children like chiefly privileges without interference. This manoeuvre demonstrates Pomare II's tie to the traditional status system even though he was responsible for the acceptance of Christianity.

7. Tahitian names were related to titles and land. Here, Teri'itaria was the wife of Pomare II and Pomare IV's mother's sister. Above Teri'itaria was the name/title given to the son of Pomare II who became Pomare III.

8. This of course being a term used by the missionaries. Many who wished to consolidate traditional rank and status used tattoo as a means of demonstrating their intentions. The missionaries saw this as reverting to past ways.

9. This was a code of laws drafted by the missionaries in consultation with Pomare II. The Code provided protection of life and property, observance of the Sabbath, sanctity of marriage, a legislature, and the abolition of some customary practices - such as tattoo and dance, and the offering of tribute.

10. Under the Pomare Code of 1819 , chiefs were appointed judges to apply the Laws of the Code. The To 'ohitu was a judicial body of seven chiefs which constituted a High Court. The chiefs who made up the To' ohitu had been district ari ' $i$ within the traditional political system.

11. From the mid 1810 s the missionaries expanded their role to include entrepreneur and advisor. These activities supported both the mission and the missionaries (see Newbury 1961, 1980).

12. Wallis arrived in Tahiti on 19 June 1767 and departed on 27 July 1767.

13. The "Declaration" as translated by Samuel Wilson on 8 September 1842:

To the Admiral Du Petit-Thouars

Because we cannot govern our government in the present circumstances so as to harmonise with Foreign Governments; and lest our land and our government and our liberty become another's, we whose names are written 
underneath - the Queen and the High Chiefs of Tahiti write to you asking that the King of the French protect us.

Here are the conditions of this agreement.

1) That the name of the Queen and the Government of the Queen and the government of the high Chiefs and their authority may remain upon them and upon their people.

2) All laws and regulations in the government established shall be made in the name of the Queen and her name signed underneath.

3) The Queen and all the people shall keep possession of their lands. Land disputes are to be left to themselves. Foreigners shall not interfere with them.

4) The people shall be left to regard God according to their own desire.

5) The Churches of the British Missionaries now existing, shall be left unmolested and the British Missionaries still discharge their functions. It is the same with all other people, they shall not be molested in their thought towards God.

Upon these conditions, if agreeable, do the Queen and the high Chiefs ask the King of the French for protection. All affairs relative to foreign Governments and concerning Foreigners resident at Tahiti shall be with the French Government and the person put in authority by said Government with the advice of her authorities — such as Port Regulations, etc Etc. And do all the functions to establish harmony and peace. (Newbury 1980: 107-8)

14. Included in this correspondence was Pomare's reason for signing the treaty. She wrote:

This is why I wrote my name, it was on account of my horror at blood being shed, and losing my Government. 5000 dollars were demanded the first day, and 5000 more on the second, or they would seize my little island, Motu-uta, and all Tahiti. Another reason for writing my name was; 'If the French Admiral were to fire upon the town, the lives of the British, American and French residents would be sacrificed'. (Pritchard 1983: 123)

15. The rivalry between the Pomare line and those descendent from the other chiefs continues today. With some of these claims comes a relationship to land which is even more problematic today due to growing populations. Many from the Tati line allege that the Pomares usurped the throne. All in all, these amount to proclamations of status, as claims no longer have a relation to power or financial gain.

16. Of her six children by Ari'ifa'aite, three had died by 1855 and Joinvile died 1875. Even though her children were in place they played little part in island politics. Ari'iaue or Pomare V married into the royal house of Huahine in 1857 but divorced in 1861. Pomare IV tried again to consolidate titles and arranged his marriage to Marau, the youngest of the Teva/Salmon line in 1875. For more information concerning the Pomare dynasty, see Henry (1928), Newbury (1980, 1988), Oliver (1974) and Stevenson (1981).

17. Under the guise of rhetoric it was revealed that the subject of the future after the death of the Queen caused a sort of restlessness among the chiefs and all the way down to the people (my translation). 


\begin{abstract}
Queen 'Aimata Pomare IV was monarch of Tahiti for 50 years (1827-77). Her reign was a time of monumental change in Tahiti. During this time Christianity became commonplace, ari ' $i$ 'chiefs' in the traditional political system became legislators in a European political system and Tahiti became French. Pomare IV worked through these changes, evolving from a non-Christian youth to a very politically shrewd stateswoman. This essay examines her life and her reign which was was mired in political conflict, opposition, intrigue and foreign intervention.
\end{abstract}

Keywords: Tahiti, Queen Pomare/Pomare IV, British missionisation, French colonialism, To'ohitu

Author contact address: Dr Karen Stevenson, 3 Avon Gate, Avonhead 8042, Christchurch, NZ. Email: ks-kf@xtra.co.nz 